\title{
Citizenship Practices Among Youth Who Have Experienced Government CARE
}

\author{
Kate Butler \\ Cecilia Benoit
}

\begin{abstract}
Expressions of youth citizenship are evident in young people's actions, behaviours, and lived experiences. While youth citizenship literature has proliferated in the last two decades, the focus has often been on rights and responsibilities, rather than the differences in citizenship practices amongst youth themselves. Using a qualitative research design, our study explores how youthwith-care-experience practice citizenship. We conducted twenty semi-structured interviews with youth-with-care-experience between the ages of 14-24 in Greater Victoria, Canada. Analysis of participants' narratives reveals three types of citizenship practices: self-responsible, dissenting and reluctant citizenship. We discuss our findings in the context of the literature on youth citizenship, focusing on the ways that it is contextualized by experiences with family, peers, institutions, and the government care system.
\end{abstract}

Keywords: Foster care; youth-with-care-experience; youth citizenship; qualitative methods; citizenship practices; responsibilization; citizenization.

Résumé. Les expressions de la citoyenneté des jeunes sont évidentes dans leurs actions, comportements et leurs expériences vécues. Alors que la littérature reliée à la citoyenneté des jeunes a proliféré dans les deux dernières décennies, l'emphase a souvent été mise sur les droits et les responsabilités, plutôt que sur les différences dans les pratiques de la citoyenneté chez les jeunes. En utilisant un modèle de recherche qualitatif, notre étude explore comment la citoyenneté est vécue par les jeunes qui ont été pris en charge. Nous avons effectué vingt entretiens semi-structurés avec des jeunes qui ont été pris en charge âgés entre 14 et 24 ans dans la région de Victoria, Canada. L'analyse des données révèle trois types de pratiques de la citoyenneté: auto-responsable, dissidente et réticente. Nous discutons de nos résultats dans le contexte de la littérature sur la citoyenneté des jeunes, en mettant l'accent sur les façons dont la citoyenneté des jeunes est contextualisée par des expériences avec la famille, les pairs, les institutions et le système de santé.

Mots clés: Familles d'accueil; jeunes-ayant-déjà-été-placés; citoyenneté des jeunes; méthodes qualitatives; pratiques de la citoyenneté; responsabilisation; rendre citoyen. 


\section{INTRODUCTION}

y oung people in late modernity negotiate citizenship through competing discourses of rights and responsibilities, and belonging and exclusion. Citizenship remains a contested concept and varies in meaning according to social, political, and cultural contexts, and different historical conditions (Lister 2007a). We operationalize citizenship as the complex and changing processes and actions of accessing rights and responsibilities, feelings of exclusion and inclusion, and participatory practices, through which individuals become embedded in communities, organizations and institutions (Beauvais et al. 2001; Smith et al. 2005). Changes in understandings of citizenship can be seen in the tensions between young people's position as active subjects, on the one hand, and dependent members of a family on the other (Cradock 2007). For young people with government care experience (henceforth referred to as "youth-with-care-experience") this position of independence and dependence is especially challenging. The ambiguity of negotiating the main dimensions of citizenship — rights, responsibilities, participation and belonging — can lead to uncertainty in youth citizenship practices.

Our paper examines some of the main ways young people with government care experience in one city in Canada practice citizenship in their daily lives. We interviewed twenty youth-with-care-experience in Greater Victoria in 2011. This research project was new, although it did include some close-ended questions from the Risky Business survey (see Benoit et al. 2008). The research provides a unique angle on youth citizenship by analyzing citizenship through the experiences of youth themselves. Although our participants tend not to use terms such as disenfranchised or marginalised or oppressed, their understandings of the limitations to expressions of their full potential certainly are present in their narratives.

The paper builds on sociological scholarship on social citizenship by exploring the citizenship rights of a relatively unexplored group: young people and, more specifically, youth-with-care-experience. This seldom heard from sub-population of youth offer insight into youth citizenship in late modernity. Youth-with-care-experience have different encounters with citizenship compared to youth who have never been in care; this is because youth-with-care-experience have a history of negotiating with the state as a parent. Thus, unlike other youth, the experience of citizenship and parenthood is not separate - a youth-with-care-experience who claims citizenship rights is making those claims not just on the state, but on the state as parent. This intimately links the practices of citizen- 
ship (of any kind) and subjectivity for youth-with-care-experience in ways not experienced by other youth.

In this paper, we first discuss the literature on citizenship and the emerging research on youth citizenship. Next, we describe the methods used to conduct the study, present our findings on citizenship practices of youth-with-care-experience, and discuss our results. We conclude with some study limitations and suggest lines of further inquiry.

\section{LITERATURE REVIEW}

T.H. Marshall's concept of citizenship is a useful way to trace the historical and social changes in the rights available to individuals in early industrial capitalist societies. Marshall (1965: 92) notes that "citizenship is a status bestowed on those who are full members of a community... All who possess the status are equal with respect to the rights and duties with which the status is endowed." Crucially, Marshall conceived of citizenship as not simply legal membership in a political community but also as a sense of belonging (Howe \& Covell 2005: 45-47). Marshall conceptualized three categories of citizenship rights - civil, political, and social; each category indicates a site of struggle around inclusion and exclusion of citizenship between individuals and the state (ibid.: 91).

It is social citizenship, which refers to individual rights of economic welfare, universal education, and social security, that provides the backbone of the modern 'welfare state' (Marshall 1965). According to Marshall (1992: 33), the outcome of the development of the welfare state is a "general enrichment of the concrete substance of civilized life, a general reduction of risk and insecurity [and] an equalization between the more and less unfortunate at all levels."

However, Marshall's work is implicitly gendered (Benoit 2000) as are much of the mainstream perspectives on welfare states in terms of the focus on social provisions for citizens (see Esping-Andersen 1990; Esping-Andersen 1996). Feminist scholars have noted that the breadwinner or citizen, whether stated explicitly or implied, is almost always considered to be male (Benoit \& Hallgrimsdottir 2011; Hernes 1987; Pateman 1988). The assumption underlying this perspective is that economic independence is essential for full citizenship, and employment is the chief distinctive feature of the [male] worker. Furthermore, there is a gendered nature to public support: men have been able to depend on employment insurance when they face unemployment, while women who rely on the government are seen as dependents (Boyd 1997). 
Just as feminist scholars have critiqued notions of citizenship that do not account for the gendered ways in which it is experienced, scholars of youth citizenship have criticised mainstream citizenship literature for overlooking youth who tend to have limited access to political and civil liberties (Hill \& Tisdall 1997; Liebel 2008; Lister 2007a, 2007b). Marshall's claim that young people are "citizens in the making" (1964: 81) has been critiqued for ignoring how youth actually enact citizenship in their daily lives (Smith et al. 2005). Youth citizenship scholars note young people are more than simply future citizens, and the concept of citizenship is applicable to youth only if its meaning is expanded. One does not simply become a citizen; rather, citizenship itself is an identity that is fluid and changing (ibid.). It is best conceptualized as a practice (Lister 2007a). The enjoyment of rights is explicitly linked to responsibilities of the individual to the state, community and to others (see Blair 1996). Practices of citizenization refer to the processes by which individuals strive for social, cultural and political citizenship (Lister 2007b). Citizenization, as a process, can be part of socialisation of an individual, much like education or the church (Tully 2008). In contemporary liberal democracies, understanding the process through which citizenship happens illustrates tensions of late capitalism, including struggles over multiculturalism, immigration, and diversity.

The responsibilities of citizenship are not experienced equally. Some individuals must continually assert (and reassert) their status as citizens by behaving in ways that are consistent with so-called good citizenship (Clarke 2005: 448). As such, individuals on the margins - including immigrants and refugees, the poor, and people of colour - have to continually prove themselves as citizens, while others take such rights for granted (Kennelly 2009; Kennelly \& Dillabough 2008). When citizenship is activated, therefore, these individuals get to be seen as citizens. However, this attainment of citizenship is fragile as it can be taken away if and when marginalised individuals do not act like good citizens. The moral component of citizenship is evident as it is up to the individual whether or not he or she will be seen by others (especially those in positions of power) as a citizen.

Literature on youth citizenship has emerged between children's rights and adult citizenship literature as a way to explore how youth access and engage with certain rights and responsibilities and how they participate in and belong to their communities (Maira 2009). Youth citizenship literature addresses questions of what it means to be a citizen and of how young people lack some of the basic rights of adult citizenship, notably the right to vote (Howe \& Covell 2005; Kennelly \& Dillabough 2008; Kulynych 2001; Maira 2009; Osler \& Starkey 2005; Roche 1999; Smith et al. 2005). There is some agreement on the components that comprise 
youth citizenship per se, beyond simply legal membership in a political community (Beauvais et al. 2001; Howe 2005; Lister 2007a). These components include rights and responsibilities, access to these rights and responsibilities, and feelings of belonging. In short, youth citizenship can be understood as the legitimating quality through which young people are entitled to participate in communities and are recognised as members by other people within communities and social institutions (Mortier 2002: 83).

Despite these recent advances, there remains limited knowledge on what it means to youth themselves to express and practice citizenship. While some research has begun to examine what citizenship means for particular groups of youth (see Kennelly 2009; Maira 2009), there are few studies that look at the changing practices of youth citizenship. Questions remain about the meaning of rights and responsibilities that matter in the everyday lives of youth, the role of belonging in determining who gets to be a citizen, and how youth participation practices intersect with citizenship rights. Our research addresses these knowledge gaps in reference to the experiences of a sub-group of youth who are in a particularly vulnerable position, youth-with-care-experience.

The focus of this study is a group of young people who can be viewed as having both opportunities and challenges in practicing citizenship. Youth-with-care-experience deal regularly with the social services system and so are aware of the legalities around making decisions about their own rights. Their interactions with the care system - both good and bad - have shaped their understandings of citizenship. If they had not been in government care, they would not have had the same opportunities to push for and enact aspects of citizenship. However, this sub-group of youth also faces numerous inequities around health care, education, work, and family support, that makes it hard for them to enact citizenship practices (Callahan \& Swift 2007; Child and Youth Officer for British Columbia [CYO B.C.] 2006; Parton 2006; Parton, Thorpe $\&$ Wattam 1997). While youth-with-care-experience and those in the general population in the province of British Columbia experienced the same common health conditions, including respiratory illnesses, injuries from motor vehicle accidents, poisoning, depression, and anxiety, those in care are diagnosed with these conditions 1.2 to 1.4 times more often than young people in the general population (CYO B.C. 2006: viii). In addition, youth who have been in care tend to have fewer resources, financial and otherwise, while in care and when they leave the care system (Fisher et al. 1986; Masten 2006; Munson, Lee, Miller, Cole \& Nedelcu 2013). They also face numerous difficulties related to education (RCY 2009), abuse (Beauvais et al. 2001), and interactions with the justice 
system (RCY 2009). Our study, therefore, highlights how citizenship is expressed by youth-with-care-experience.

\section{Methods}

Using a qualitative research strategy, we conducted twenty semi-structured interviews in Victoria, Canada with youth ages $14-24^{1}$ who had previously been in government care in Canada (see Table 1). Victoria, the capital of British Columbia, has a population of about 80,000 people, while Greater Victoria includes almost 350,000 , making it the $15^{\text {th }}$ largest metropolitan area in Canada (Statistics Canada 2011), and is similar in makeup to other middle-sized metropolitan areas in Canada. By conducting our study in Greater Victoria, we had access to urban, suburban and rural youth, as well as Aboriginal youth living on and off reserves. We asked participants to narrate their experiences with citizenship, rights and responsibilities, and belonging and/or exclusion.

We used non-random purposive sampling, which means that the selection of participants was based on a specific criterion (Cresswell 2003 ); in this case, previous experience in government care. ${ }^{2}$ Purposive sampling was useful as we were able to find participants who shared this particular characteristic, thereby allowing for an investigation of themes across and within their responses (Ritchie, Lewis \& Elam 2003: 78). Although this process involved deliberate choices, it did not mean that undue bias was involved in the choices that were made. Instead, participants were recruited from youth-serving agencies because they illustrated characteristics that allowed us to consider a phenomenon in greater detail (Neuman \& Robson 2009: 137-8). To better understand citizenship practices in participants' lives, we chose to conduct qualitative in-depth interviews. A qualitative orientation allows us to focus on the 'thick descriptions' of these experiences, as described by participants in interviews. In doing so, we gain a deeper understanding of the social and cultural meanings of participants' experiences with and in their relationship to citizenship.

The interviews began with close-ended background questions about participant experiences in government care and with parental and/or

1. While youth is a contested term, we use the age range of 14-24 because it reflects the terminology used by youth-serving organizations in Greater Victoria, as well as government agencies such as the British Columbia Representative for Children and Youth [RCY].

2. With this in mind, participant characteristics of the sample, such as gender, Aboriginal status, visible minority status and sexual orientation, are not indicative of the care population in British Columbia. 
non-parental guardians. We used probes to elicit further detail about certain answers or comments. In terms of experiences in government care, participants described a variety of situations that led them to being in care, as well as to leaving care. Eight participants experienced only 1 care home or facility, four were in 2-3 care homes, four were in 4-7 care homes, and four were in 8 or more care homes. Participants described differing experiences in terms of years in care: ten participants spent less than two years in care, five participants spent 2-4 years in care, and five spent longer than 4 years in care. As for age when entering care for the first time, three participants were aged 2 or under, two participants were aged 3-9, ten participants were aged 10-13, and five were ages 14 and over.

We then introduced participants to the United Nations Convention on the Rights of the Child (UNCRC) through a short oral overview describing what the Convention's purported aims were, what Canada's expressed commitments to the Convention are, and what rights youth have access to, according to the Convention (UNCRC 1989). The reason for introducing the UNCRC is that the Convention places an emphasis on the autonomy of young people, particularly as it relates to the best interests of the child or youth in question. The UNCRC is not without controversy: youth were involved only peripherally in the writing and drafting of the document (Liebel 2008); furthermore, the UNCRC is a 'consensus document' in the sense that it had to adhere to the lowest common denominator - what everyone could agree upon as rights young people all over the world needed. Nevertheless, the document does provide a framework through which to view the parameters of citizenship for youth. The Canadian and provincial governments, like many other jurisdictions around the world, have used the UNCRC as a basis for framing youth rights, responsibilities, and citizenship in policies and legislation (Covell \& Howe 2007). Following this introduction to the UNCRC were questions to participants about rights, citizenship, and community in their daily lives. Additionally, we asked about their interactions with various service providers and outreach agencies. We wanted to know how these institutional representatives affected the youth's lives from the point of view of the youth themselves. ${ }^{3}$

Data analysis, conducted using transcripts of the interviews, involved an analytical hierarchy strategy, which includes data management, indexing and categorization (Spencer, Ritchie \& O'Connor 2003a; 2003b). Spencer, Ritchie \& O'Connor (2003a: 213) argue that this data analysis technique is particularly useful for research analysis based on interpretations of meaning. An analytical hierarchy strategy allows for the iden-

3. See Appendix A for an abbreviated interview guide 
tification of key descriptive dimensions and accounts, and encourages a move towards "patterns of association" in the data while looking for linkages between and across accounts (Spencer, Ritchie \& O'Connor, 2003a: 215). In doing this, we were able to ascertain associations and themes that were central to understanding youth citizenship practices, which we explore in the following results section.

\section{Results}

To understand how youth practice citizenship, our interviews explored their experiences with rights, responsibilities, institutions, and community organizations. Our analysis revealed participants' understandings of citizenship, even when they did not initially identify with the term. Participants' responses illustrate the barriers and possibilities for practicing citizenship that youth saw in their own lives. The three main ways participants practice citizenship are what we have termed self-responsible citizenship ( $\mathrm{N}=6$ participants), dissenting citizenship ( $\mathrm{N}=5$ participants) and reluctant citizenship ( $\mathrm{N}=9$ participants). Citizenship is enacted, described and embodied by participants in their homes, schools and communities.

\section{Self-responsible citizenship}

Self-responsible citizenship is expressed by youth as indicative of being productive members of society. Being a self-responsible citizen means participating in the labour market, volunteering based on individual goodwill and virtue, and pursuing education as a means to get ahead (Maira 2009: 136-7). Expressions of self-responsible citizenship are also evident in participants' emphasis on individual responsibility. Participants espouse the idea that everyone has equal opportunities, and that it is up to the individual to be resilient as citizens. Self-responsible citizenship involves a constant activation of citizenship duties and practices, in order to continue to embody 'good' citizenship (Clarke 2005).

Youth practicing self-responsible citizenship are comfortable discussing the responsibilities that they associate with being a citizen, framing their conceptions of citizenship in terms of individual activities. Karina, age 19, associates citizenship with being in Canada legally:

Somebody who has... the rights of the country. So somebody who was born there or who has landed in the country. But if you're an illegal alien, then you're not going to have those rights 'cause you're not supposed to be there. 
Being a citizen is thus a badge worn only by those who are seen as legitimate, and legality is equated with good citizenship.

Discussions about responsibilities often emphasize the role of work in legitimating citizenship. Pierre, age 22, says he is not a good citizen right now because he does not have a job: "Not right now anyways... I don't have a job." He goes on to say that a job is "the common thing that people see as being a good (citizen)." Karina, age 19, also sees having a job as a central responsibility of a citizen:

... to be respectful of those around me and try [to] provide for myself and not rely on the government, and have a job and keep order and peace.

This meaning of citizenship is consistent with Rose's (1996) concept of responsibilization, in which individuals take on social risks as their own. Participants expressing this type of citizenship see personal responsibility and hard work as one of the main ideas that young people need to learn. Tyler, age 20, comments on the subject as follows:

You got a be a productive human or else life's going to be really difficult on you. [L]ife's not going to just hand it to you on silver platter. You have to go out there and get it.

This idea that he needs to be productive because everything will not be handed to him fits closely with the self-responsible version of what 'good' citizenship looks like (see Blair 1996; Hayward 2012). Part of being a self-responsible citizen is making good choices: the individual is at the centre of this narrative of citizenship. Sophie, age 21, and a single parent, states she needs to make better choices: "I screwed up and went to jail... I just needed to make better choices for my kids." Similarly, Becky, age 22, sees herself as responsible for ending up in unsafe situations, including times when she was raped, in an abusive relationship, as well as when she was almost kidnapped and attacked. She states she now knows how to "keep myself out of situations like that." Sophie and Becky have internalized 'women's safety talk' which illustrates that male violence can operate as a self-regulating technology for women (Stanko 1997).

Being a self-responsible citizen, therefore, is about being accountable for one's personal choices. A self-responsible citizen, in their view, manages one's own life without surveillance from social service workers, parents, foster parents, or probation officers and also without support 
from the state in the form of income and/or disability assistance. ${ }^{4}$ The notions of choice and free will are apparent in self-responsible citizenship; they indicate that youth embracing this kind of citizenship see it as something they can control. Within this framework, individuals will find themselves on the path to citizenship if they make good choices. Conversely, those who make bad choices - such as Becky sees herself as having made when she was raped - are responsible for whatever happens.

For those practicing self-responsible citizenship, being a citizen is something they can aspire to: it means acting like an idealized adult, fitting into societal roles, having a secure well-paying job, and being a cooperative community member. These young people see good citizens as jobholders, individuals who are not dependent on the government, and are integrated into mainstream society. Our participants holding this view want to be part of this trajectory, even if they feel like they are not yet considered to be 'good' citizens. These participants attempt to lead 'normal' lives and participate in practices that they see as virtuous and desirable.

\section{Dissenting citizenship}

We now turn to participants who reject the premise that being a citizen meant helping oneself first and foremost. Although youth are often inundated with images of the good, self-responsible citizen, it is crucial to note that even marginalised youth have varying degrees of agency in how they read these images and their relationship to the dominant discourses surrounding such images. It is not enough to say that there are structural constraints in place that limit citizenship expressions to a selfresponsibility model: instead, some young people, despite significant disadvantage, express citizenship by distancing themselves from this ideology. Maira (2009) calls this 'dissenting' citizenship in her discussion of Muslim youth in post 9/11 America. For our participants, challenging mainstream citizenship discourses means rebuffing the idea that individual responsibility is the only way to see or do citizenship. These participants also recognize the structural constraints that exclude some people from being considered citizens, as well as the systemic barriers restricting them from reaching their potential.

4. It should be noted that Aboriginal Canadians have not been given the option to manage their own lives without surveillance due to racist policies around residential schooling in British Columbia (and the rest of Canada) over the last 150 years. As well, the relationship between Aboriginal Canadians and work has been complicated by the exclusion of Aboriginal Canadians from the market economy in the late $19^{\text {th }}$ and early $20^{\text {th }}$ century (Knight 1996). 
For those expressing dissenting citizenship, the responsibilities of citizenship are often institutionally-based. These participants are aware of the complex ways that young people become street involved, and the institutional constraints that may limit their subsequent choices and options. As Robert, age 21, notes, opportunities are needed for youth who are struggling:

[A] good home growing up, not get kicked out on the streets, get your education and go to the college. Maybe your parents can help you with some rent when you're doing that to start you off as a boost. When you don't have that boost, it's going to be hard.

Lauren, age 16, also comments on how people who live on the streets need opportunities and help:

I wouldn't have been able to do it (live on the street) if someone didn't realize, 'oh, ok, there's homeless people, well, we need a place called a homeless shelter', or 'we should give out food on these days'. I wouldn't have survived without that. (I)t needs to be facilitated to some extent; you need opportunities too.

This recognition of the responsibility of institutions in facilitating opportunities for youth to practice citizenship speaks to the structural and contextual factors in everyday expressions of citizenship.

For young people who practice dissenting citizenship, being a citizen also means taking actions and making decisions about their own lives and about the well-being of their local community, and often other communities in which they are involved. Hayward (2012) notes that all young people have 'social agency' to organize and collaborate for the common good. Participants discuss strategies to take control of their own lives and reach out to others in their community, particularly youth who are in similar situations. As Jenna, age 20, states:

I'm able to relate in a lot of different areas with a lot of youth and even older people because I have a lot of patience. I listen to others (and say) 'well this is what I think and this what I did... I think this was the right decision for me,' or 'I regret making this decision,' and it helps make a decision for them.

Instead of putting up with practices that they felt to be unjust, youth who express dissenting citizenship also take action to make changes. Sawyer, age 22, describes what this means for him: 
I've broken up so many fights out there between the youth that it's not even funny. I know it's not my job but they just sell drugs to each other, they do gangster (stuff), they graffiti the walls. I'm out there to prevent the graffiti, but I'm also there to make sure no girls get hurt and abused and men don't beat each other up over testosterone driven gangster mumbo jumbo.

According to Elliott, age 19, having social agency means the option to exercise the right to protest against issues you disagree with: "You have the right to protest, or disagree with the government, or to just say whatever you want." Exercising citizenship is therefore emblematic of the relatively traditional form of citizenship wherein one's protesting of government is important. Few youth mentioned revolutionary means of being a citizen, but there was certainly a cognizance amongst dissenting citizens as to the importance of free speech. Acting in the public sphere becomes part of these youths' citizenship practices.

Practicing dissenting citizenship can additionally be about challenging the norms of self-responsibility, particularly the focus on citizenship as being about individual self-help. As Jenna, age 20, notes:

[I]f I see somebody that needs a hand, (I) help them out, and if I'm going to go do to the youth clinic, people ask me for advice... I tell them how I see things and my opinion on things and they don't always have to agree but it just helps them see through other eyes.

Lauren, age 16, also discusses her attempts to create change:

I started performing my rap music at cafes... I worked myself up to going to big meetings with people in the government making decisions for youth, and I went there telling my story, giving a speech and explaining what happened... And, then rapping for them. That way my voice is heard, and that's the only way people have ever listened to me....

Lauren's ability to speak to adults about personal and public issues is likely in part a result of her experiences in and out of the government care system. Participants who practice dissenting citizenship emphasize collective responsibilities and the role of youth as social agents. In many ways, dissenting citizenship illustrates that rights and responsibilities are not always the most relevant ways to frame discussions. Rather, practicing citizenship involves a reframing of self as an actor in a community, and as a participant in one's own citizenship narrative. 


\section{Reluctant citizenship}

Some participants indicate discomfort with the term citizenship, and question the practices that are commonly associated with the term. These 'reluctant citizens' specify uncertainty, disinterest, and apathy towards standard citizenship practices. In some ways, the reluctant citizen resembles Merton's (1957) 'retreatist' who rejects cultural goals and institutional means in order to escape from the pressures and demands of organized society. Participants practicing reluctant citizenship have no interest in being part of mainstream goals expressed by those who endorsed self-responsible citizenship, and also are not interested in dissenting citizenship practices that privileged alternative ways of being or expressing citizenship. Reluctant citizenship practices do not challenge the status quo; rather these practices can be seen through expressions of exclusion and apathy. In some ways, they espouse an emotional distance from the very idea of citizenship. Tyler, age 20, states the laws that citizens must follow often make little sense: "the laws are obviously applied for a reason, (but) some of them are bogus and weird." Participants who practice reluctant citizenship express their rejection of citizenship norms as pertinent to their own lives. They do not see themselves as 'doing' citizenship or 'being' a citizen. They frame being a citizen as something that happened to others rather than themselves; they instead talk about their rights and responsibilities as secondary to other dimensions of their lives. As Blake, age 19, notes, a citizen is someone who "takes a test." This association of citizenship with something others do illustrates the unease that this group of participants felt with the concept. The responsibilities of a citizen are also seen to be different from what they see happening in their own lives. Taryn, age 20, states citizens need to avoid "being in trouble like by (the) law and (being) good", but that now that she is not working, her daily routine consists of "blazing everyday, (as) drinking and smoking is not a big deal to me." She goes on to note that citizens have jobs; while she wants a job, she cannot find one and does not want to look.

This rejection of citizenship norms is evident in participants' disavowal of participation as a way to express citizenship. Taryn sees participating in school or the community as about being able to do what "normal people do"; she does not consider herself to be normal so she does not think of herself as participating. Others mention they cannot act as citizens because it requires resources they do not possess. Ruby, age 22, notes: 
[I]t's hard for the youth to be open, because everybody's like, 'oh, you don't have nice shoes, or you don't have this, or you don't have that,' and then kids make fun of you.

Participation, therefore, is not something available to these young people or what they necessarily want to be bothered with. In fact, participating in something like a protest or voting in an election was dismissed by these participants as relatively useless. Molly, age 24 says:

I find that voting doesn't get me very far. I can yell and scream about the fact that the government no longer pays for my birth control (but nothing happens).

Reluctant citizenship participants express disillusionment with mainstream society, including its citizenship discourses. Ruby, age 22, talks about the reasons she rejected pursuing self-responsible citizenship ideals:

I lived out in the woods and didn't want to be part of society, I didn't want to have the government know how much money I made and I thought it was stupid that you had to pay for food when you need it... food should be free.

These participants are ambivalent to the values they see as normal, and their dissatisfaction is often linked to experiences of exclusion. Participants note how they are made to feel like they do not fit in at home, at school, or anywhere. The reluctance of these individuals to embrace the concept of citizenship illustrates the challenges with the meaning of youth citizenship itself: if citizenship does not resonate with youth themselves, is it still a valuable way to assess the lives and practices of young people? This question is even more crucial as almost half the participants most identify with reluctant citizenship. The alienation and withdrawal that these youth express may have consequences for later adult citizenship practices.

Self-responsible, dissenting, and reluctant citizenship practices illustrate the variety of ways that our participants negotiate their lives as citizens in one community in Canada at present. Many youth in our study discussed being excluded formally and informally from full participation in the institutions and structures that grant access to basic rights, but they still expressed citizenship in their own terms. Their relationship to the idea of citizenship was contextualized by the structural realities of their own life histories, as well as cultural, social, and economic factors. 


\section{Discussion}

Practicing citizenship encompasses many aspects of participants' lives, and being a citizen is not something that all participants embrace easily. Tension between wanting to be a citizen, on one hand, and not knowing how, on the other, constrained the ways that their citizenship practices took shape. In this section, we explore how citizenship is differentiated, why age matters, and how it can be seen as a strategy for connecting with the community.

Citizenship is differentiated by gender, class, age, race, and sexuality (Hankivsky and Christoffersen 20089; Hankivsky et al. 2010; Hill and Tisdall 1997; Liebel 2008; Lister 2008; Young 1995). In our study, participants describe, enact and embody citizenship practices in particular ways which illustrate that sources of difference were evident to them. For instance, gendered experiences of citizenship for youth can be evidenced in how some of the young women participants foregrounded their experiences as mothers in their understandings of what their rights were, how they practiced responsibility, and what they thought about participation and belonging. Similarly, discussions of safety in the community illustrate the different ways that women and men conceptualized the right to protection, which may have influenced the way that they practiced citizenship. There were also examples in the narratives of citizenship in which sexual orientation and ethnicity became a part of citizenship practices through negotiations of belonging, and experiences of difference.

All youth, not just youth-with-care-experience, face barriers when it comes to practicing citizenship in that they tend to be seen as less capable than adults of being citizens (Cohen 2005). As Smith et al. (2005: 429) note, youth are socially constructed as 'distinct from' and 'other than' adult citizens. Ageism, understood as discrimination based upon "beliefs about the impact of biological ageing on people of all ages, which relates to fear and prejudice throughout the life course" (Bytheway 2005: 361), is a problem faced not just by marginalised youth but by youth more generally, as they have traditionally been seen as citizens in the making rather than citizens now (Marshall 1964). However, to an even greater degree, youth with fewer access to resources are constituted by others as less than ideal citizens (Blanchet-Cohen \& Salazar 2009), and must prove that they are capable of expressing citizenship in a normative way. For the young people in our study, citizenship had to be constantly reactivated: their citizenship status was only as good as the current ways they practiced it. For instance, the reliance on paid work as indicative of good citizenship, expressed by most participants even though some were 
critical of this criterion, illustrates how self-responsibility as an ideal for all individuals has permeated the consciousness of participants.

Practicing citizenship is also a strategy for some youth to connect to the world around them. While participants often discuss themselves as lucky or hard-working in their narratives, they additionally touch upon how their lives, and their citizenship practices, are shaped by outside forces, including other individuals. One way that this comparison occurs is by invoking a "generalized other" (Mead 1962) to whom they could refer to when thinking about life chances, choices and citizenship practices. Often, they compare the choices they made to what they thought the generalized other would think of them. This comparison to the generalized other illustrates how youth-with-care-experience imagine themselves as ingrained into a broader picture. Even while they talk about individual difficulties that they experienced, youth were still keen to talk about how their lives 'fit in' with family, the local community, and the Greater Victoria region. In discussing what citizenship practices entail, these youth envisioned and embodied citizenship as a part of their own daily lives, and, at the same time, as a part of other processes and structures to which they belong, even tangentially.

Practicing citizenship is best conceptualized as involving action, as well as experiences and expressions within particular historical and social contexts. Differential social locations of subjects (or intersectional standpoints) enable and constrain possibilities of citizenship (Anthias \& Yuval-Davis 1992; Collins 2000). Thus practicing citizenship must be seen through a lens that recognises the structural as well as the agential aspects of individual's lived experiences. The experiences in government care play a role in shaping how these young people come to the process of citizenization (Lister 2007b; Tully 2008). They learn how to 'do' citizenship through interactions with institutions that they are forced to confront, and with interactions with foster care, the justice system, social workers, and child and youth workers. Moreover, recognizing the social reality of individuals means taking into account how social, cultural, economic, and political dynamics are determined simultaneously and interactively through various axes of social organization (Stasiulis 1999: 345). How youth practice citizenship occurs in a context of institutional and structural realities, as well as through individual actions.

\section{LIMITATIONS AND FUTURE RESEARCH}

While this research has illustrated the complexities of citizenship practices of youth-with-care-experience, there are limitations to our study. 
Our relatively small sample, coupled with the single method for examining citizenship (in-person interviews), means that we likely have missed some of the ways that citizenship is practiced or expressed. This also limits our ability to make claims about the clustering of citizenship practices in relation to variables such as years in government care, education, ethnicity, Aboriginal status, or gender of participants. We thus cannot look at the similarities or differences across group characteristics to gain insight into how particular intersecting identities are experienced by youth-with-care-experience.

Future research focused on youth-with-care-experience could address these limitations by using a mixed methods approach, including different individuals for interviews (such as foster parents or social workers), or engaging in an ethnography with youth-with-care-experience. More research in this area could potentially contribute deeper understanding to how intersections of diversity, inequality and resilience matter in the citizenization process.

\section{Conclusion}

Expressions of citizenship by youth-with-care-experience illustrate tensions between self-responsibility and rights, exclusion and inclusion. It is useful to consider how youth who have not been in government care practice citizenship, and whether there are similarities with the non-care youth population and our participants. While these two groups of youth (those with care experience and those without) are of the same age and likely share similar anxieties about their lives as emergent adults, one major difference is that youth-with-care-experience have had the government as their primary guardian. Similar to more privileged youth, youth-with-care-experience are navigating challenges linked to fragile family and peer relations, tenuous connections to school, and questions about belonging. However, the position that our participants occupy as former wards of the state in an era of self-responsibility - means they have to negotiate their own citizenship within a context of changing care homes, transient living situations, and relations with social workers, judges, and other youth workers. A diversity of citizenship practices is not surprising considering the variety of situations that participant youth encounter in their lives; the similarities and commonalities that do exist, therefore, can highlight some of the challenges of creating and sustaining an inclusive view of youth citizenship for marginalized young people. 


\section{REFERENCES}

Anthias, Floya \& Nira Yuval-Davis. 1992. Race, Nation, Gender, Colour and Class and the Anti-Racist Struggle. London: Taylor and Francis.

Beauvais, Caroline, Lindsey McKay, \& Adam Seddon. 2001. A literature review on youth and citizenship. Canadian Policy Research Networks. Ottawa, ON.

Benoit, Cecilia, Mikael Jansson, Helga Hallgrimsdottir, \& Eric Roth. 2008. Street youth's life course transitions. Comparative Social Research 25: 329-357.

Benoit, Cecilia \& Helga Hallgrimsdottir. 2011. Valuing Care Work: Comparative Perspectives. Toronto: University of Toronto Press.

Blair, Tony. 1996. New Britain: My Vision of a Young Country. London, UK: Fourth Estate.

Blanchet-Cohen, Natasha, \& Jorge Salazar. 2009. Empowering practices for working with marginalized youth. Relational Child and Youth Care Practice 22(4): 5-15.

Boyd, Susan. 1997. Challenging the Public/Private Divide: Feminism, Law, and Public Policy. Toronto, ON: University of Toronto Press.

Bytheway, Bill. 2005. Ageism and age categorization. Journal of Social Issues 61(2): 361-374.

Callahan, Marilyn \& Karen Swift. 2007. Great expectations and unintended consequences: risk assessment in child welfare in British Columbia. In People, Politics, and Child Welfare in British Columbia, edited by L.T. Foster and B. Wharf, 158-183. Vancouver, BC: UBC Press.

Child and Youth Officer for British Columbia. 2006. Joint Special Report: Health and Well-Being of Children in Care in British Columbia: Report 1 on Health Services Utilization and Mortality. Ministry of Health Office of the Provincial Health Officer. http://www.health.gov.bc.ca/pho/pdf/ cyo/complete joint report.pdf

Clarke, John. 2005. New Labour's citizens: activated, empowered, responsibilized, abandoned? Critical Social Policy 25(4): 447-463.

Cohen, Elizabeth F. 2005. Neither seen nor heard: children's citizenship in contemporary democracies. Citizenship Studies 9(2): 221-240.

Collins, Patricia H. 2000. Black Feminist Thought: Knowledge, Consciousness, and the Politics of Empowerment, ( $2^{\text {nd }}$ ed.). New York: Routledge.

Corsaro, William. 1997. The Sociology of Childhood. Thousand Oaks, CA: Pine Forge Press.

Cradock, Gerald. 2007. The responsibility dance: creating neoliberal children. Childhood 14(2): 154-172. 
Cresswell, John. 2003. Research Design: Qualitative, Quantitative and Mixed Methods Approaches, (2 ${ }^{\text {nd }}$ ed.). Thousand Oaks, CA: Sage Publications.

Esping-Andersen, Gosta. 1990. The Three Worlds of Welfare Capitalism. Princeton, NJ: Princeton University Press.

Esping-Andersen, Gosta. 1996. Welfare States in Transition: National Adaptations in Global Economies. London: Sage Publications.

Fisher, Mike, Peter Marsh, \& David Phillips. 1986. In and Out of Care: The Experiences of Children, Parents and Social Workers. London, UK: Batsford in association with British Agencies for Adoption and Fostering.

Hallgrimsdottir, Helga, Cecilia Benoit, \& Rachel Phillips. 2013. The mothercitizen and the working girl: first wave feminist citizenship claims in Canada and discursive opportunities for twenty-first century childcare policy. Canadian Review of Sociology 50(1): 27-51.

Hankivsky, Olena \& Ashlee Christoffersen. 2008. Intersectionality and the determinants of health: a Canadian perspective. Critical Public Health 18(3): 271-283

Hankivsky, Olena, Colleen Reid, Renee Cormier, Cecilia Benoit, Shari Brotman, Natalie Clark, and Colleen Varcoe. 2010. Exploring the promises of intersectionality-type methodologies for advancing women's health research. International Journal for Equity in Health 9(5).

Hayward, Bronwyn. 2012. Children, Citizenship and Environment: Nurturing a Democratic Imagination in a Changing World. New York: Routledge.

Hernes, Helga.M. 1987. Welfare State and Woman Power: Essays in State Feminism. Oslo: Norwegian University Press.

Hill, Malcolm \& Kay Tisdall, 1997. Children and Society. Cambridge: Cambridge University Press.

Howe, Brian 2005. Citizenship education for child citizens. Canadian and International Education 34(1): 41-49.

Howe, Brian \& Katherine Covell. 2005. Empowering Children: Children's Rights Education as a Pathway to Citizenship. Toronto, ON: University of Toronto Press.

Kennelly, Jacqueline. 2009. Good citizen/bad activist: the cultural role of the state in youth activism. The Review of Education, Pedagogy and Cultural Studies 31: 127-149.

Kennelly, Jacqueline \& Jo-Anne Dillabough. 2008. Young people mobilizing the language of citizenship: struggles for classification and new meaning in an uncertain world. British Journal of Sociology of Education 29(5): 493-508.

Knight, Rolf. 1996. Indians at Work: An Informal History of Native Labour in British Columbia, 1858-1930, (2 ${ }^{\text {nd }}$ ed.). Vancouver, B.C.: New Star Books. 
Kulynych, Jessica. 2001. No playing in the public sphere: democratic theory and the exclusion of children. Social Theory and Practice, 27(2): 231-264.

Liebel, Manfred. 2008. Citizenship from below: children's rights and social movements. In Children and Citizenship, edited by A. Invernizzi \& J.M. Williams, 32-43. Los Angeles, CA: Sage Publications.

Lister, Ruth. 2007a. Why citizenship: where, when and how children? Theoretical Inquiries in Law 8(2):Article 13.

Lister, Ruth. 2007b. Inclusive citizenship: realizing the potential. Citizenship Studies 11(1): 49-61.

Lister, Ruth. 2008. Unpacking children's citizenship. In Children and Citizenship, edited by A. Invernizzi \& J.M. Williams, 9-19. Los Angeles, CA: Sage Publications.

Maira, Sunaina. 2009. Missing: Youth, Citizenship, and Empire after 9/11. Durham, NC: Duke University Press.

Marshall, Thomas H. 1964. Citizenship and social class. In Class, Citizenship and Social Development, edited by T.H. Marshall, 70-118. New York: Doubleday.

Masten, Ann S. 2006. Promoting resilience in development: A general framework for systems of care. In Promoting Resilience in Child Welfare, edited by R.J. Flynn, P.M. Dudding, \& J.G. Barber, 3-17. Ottawa, ON: University of Ottawa Press.

Mead, George. 1962. Mind, Self, and Society. Chicago: University of Chicago Press.

Merton, Robert K. 1957. Social Theory and Social Structure. New York: Free Press of Glencoe.

Mortier, Freddy. 2002. The meaning of individualization for children's citizenship. In Childhood and Children's Culture, edited by F. Mouritsen \& J. Qvortrup, 79-102. Odense, DK: University Press of Southern Denmark.

Munson, Michelle, Bethany R. Lee, David Miller, Andrea Cole, \& Cristina Nedelcu. 2013. Emerging adulthood among former system youth: the ideal versus the real. Children and Youth Services Review 35: 923-929.

Neuman, Lawrence \& Karen Robson. 2009. Basics of Social Research: Qualitative and Quantitative Approaches. Toronto, ON: Pearson.

Osler, Audrey \& Hugh Starkey. 2005. Changing Citizenship: Democracy and Inclusion in Education. Berkshire, U.K.: Open University Press.

Pateman, Carole. 1988. The Sexual Contract. Stanford, CA: Stanford University Press.

Parton, Nigel. 2006. Safeguarding Childhood: Early Intervention and Surveillance in Late Modern Society. Houndmills, Basingstoke, Hampshire, UK: Palgrave Macmillan Press. 
Parton, Nigel, David Thorpe, and Corrine Wattam. 1997. Child Protection: Risk and the Moral Order. Houndmills, Basingstoke, Hampshire, UK: MacMillan Press.

Representative for Children and Youth (RCY) and B.C. Office of the Provincial Health Officer. 2009. Kids, crime and care: health and well-being of children in care: youth justice experiences and outcomes. Victoria, B.C.: British Columbia Representative for Children and Youth.

Roche, Jeremy. 1999. Children: rights, participation and citizenship. Childhood 6(4): 475-493.

Rose, Nikolas. 1996. Powers of Freedom: Reframing Political Thought. Cambridge: Cambridge University Press.

Shaw, Mae \& Ken McCulloch. 2009. Hooligans or rebels: thinking more critically about citizenship and young people. Youth and Policy 5-14.

Smith, Noel, Ruth Lister, Sue Middleton, \& Lynne Cox. 2005. Young people as real citizens: towards an inclusionary understanding of citizenship. Journal of Youth Studies 8(4): 425-443.

Stanko, Elizabeth. 1997. Safety talk: conceptualizing women's risk assessment as a 'technology of the soul'. Theoretical Criminology 1(4): 479-499.

Stasiulis, Daiva. 1999. Feminist intersectional theorizing. In Race and Ethnic Relations in Canada, ( $2^{\text {nd }}$ ed.) edited by P. Li, 347-397. Toronto, ON: Oxford University Press Canada.

Statistics Canada. 2011. National Household Survey: Income and Housing. Government of Canada.

Thomson, Rachel, Janet Holland, Sheena McGrellis, Robert Bell, Sue Henderson, \& Sue Sharpe. 2004. Inventing adulthoods: a biographical approach to understanding youth citizenship. The Sociological Review 52(2): 218239.

Tully, James. 2008. Two meanings of global citizenship: Modern and diverse. In Global Citizenship Education: Philosophy, Theory and Pedagogy, edited by M.A. Peters, A. Britton, \& H. Blee, 15-39. Rotterdam: Sense Publishers

United Nations Convention on the Rights of the Child. 1989. Convention on the Rights of the Child, Geneva: United Nations.

Young, Iris Marion. 1995. Mothers, citizenship and independence: a critique of pure family values. Ethics 105: 535-556. 
Appendix A: ABbreviated interview GUide

\section{INTERVIEW QUESTIONS}

Before asking questions rights and citizenship, we asked some background questions around demographics, care placements and relationships with adults in participants' lives. These have not been included in this abbreviated interview guide.

We're now going to turn to our discussion on human rights, and what these rights mean to you. According to the United Nations Convention on the Rights of the Child, every young person has certain rights. The UNCRC, which I will refer to as the Convention, is signed by almost every country in the world. It states that all young people have the right to protection, provision (meaning food, survival), and participation. For this part of the interview, we discuss how you access these rights in your daily life, what you think these rights mean, and whether rights are a useful way to think about your life. To answer some of these questions, I am going to ask you to think back to when you were in care, and how you accessed your rights then. Remember, if you are uncomfortable answering any of the questions, we can stop the interview at any time.

1. First of all, lets talk about what we mean by rights. When you think of human rights, what comes to mind? Can you name some human rights? In general, who lays out or decides what rights are, and who gets which rights?

2. We often talk about rights in relation to citizenship. What or who is a citizen? Is being seen as a citizen something that is desirable? What does the term citizenship mean to you? In general, what are the responsibilities of a citizen?

3. Responsibilities are often talked about as the 'other side' of having rights. What are your responsibilities in your daily life? Describe how you deal with these responsibilities.

4. We're now going to turn to what rights look like in your daily life. As mentioned, according to the UNCRC, there are rights to protection, provision and participation. These are broad categories that encompass a lot of different 'rights'. We're going to start with the survival or development rights that young people have to basic economic well-being and security. First of all, what does it mean to have the right to survival or development? What do young people need to survive or develop? 
5. When you were in care, who provided you with the necessities that were basic for your survival (food, shelter)? What was your role in providing for your own survival and development? What is your role now in providing for your survival and development?

6. Rights to survival and development also involve health care. Can you tell me about your experiences with having access to health care? What do youth need in terms of accessing healthcare?

7. Now, lets turn to the right of the young person to be protected. Young people are supposed to be protected against all forms of physical and mental violence, injury, or abuse, neglect and exploitation by parents or others in positions of authority. We know that this is not always the case. In your life, what has this right looked like? Thinking back to when you were in care, how did you have access to this right? In what ways have you not felt like you have had this right?

8. This right also has to do with how safe you feel in your community. Have you usually felt safe in your community? In your current life, how do you feel safe in your community?

9. Rights to protection also have to do with treatment in the criminal justice system. Can you talk about any experiences you've had with the criminal justice system? (Experiences with police, social services)

10. The third set of rights that the UNCRC lays out for youth is the right to participation. What do you think it means to have a right to participate? What is participation? In what areas of their lives should young people be able to have a voice/participate?

11. I now want to discuss how you participate in your family life while in care, school, and in the community. Lets start by thinking back to when you were in care, and when you were growing up (before care if applicable). How did you participate in decisions about your family? Did you participate in decisions about friends? Dating? Vacations? As you got older, how did your participation in family life change?

12. Next, lets turn to your participation in or at school. First, can you tell me about your experiences at school while being in care or growing up?

13. When you were growing up, how did you participate in school activities or school-sponsored activities? And in your life now, how do you participate in school activities or in the classroom? What about school-sponsored activities outside of school? Are 
there specific challenges that the school system poses for youthin-care?

14. Lets now turn to the community. First of all, what is a community? Who or what is your community now? How did you make or create this community? What makes a good community? Growing up, would you say that you participated in your community? If so, how?

15. What role do you think youth should play in making decisions in their communities? Is participation of youth in communities important? What are some challenges that youth face in participating in their communities?

16. Do you think your experiences of accessing your rights are similar to other youth? Why or why not?

17. Are there specific challenges that you think youth-in-care face that other youth do not?

18. How did your experiences of being a youth-in-care make you who you are today? Work? Child-raising? Relationships?

19. Thinking about the future, what would you like to do as an ideal career? What are some challenges you see with this?

20. Finally, we have been talking about rights, and what rights young people have. There is still a lot of confusion about this topic. How did you learn what you know about rights? Did you learn about this in school? How do you think we can better talk to youth about rights?

21. With that last question, we have concluded the interview. Are there any other comments you want to make about rights?

\section{TABLES}

Table 1: Participant Characteristics

\begin{tabular}{|c|c|c|c|c|c|c|c|c|}
\hline \multicolumn{9}{|c|}{ Participant Characteristics } \\
\hline & \multicolumn{2}{|c|}{ Aboriginal Status } & \multicolumn{2}{|c|}{ Visible Minority } & \multicolumn{2}{|c|}{$\begin{array}{c}\text { Sexual } \\
\text { Orientation }\end{array}$} & \multicolumn{2}{|c|}{ Age } \\
\hline & $\begin{array}{l}\text { Identify as } \\
\text { Aboriginal }\end{array}$ & $\begin{array}{c}\text { Identify as } \\
\text { Non- } \\
\text { Aboriginal }\end{array}$ & $\begin{array}{c}\text { Identify as } \\
\text { visible } \\
\text { minority }\end{array}$ & $\begin{array}{c}\text { Do not } \\
\text { identify as } \\
\text { visible } \\
\text { minority }\end{array}$ & $\begin{array}{l}\text { Identify } \\
\text { as non- } \\
\text { straight }\end{array}$ & $\begin{array}{l}\text { Identify } \\
\text { as } \\
\text { straight }\end{array}$ & $19<$ & $20+$ \\
\hline Male & 1 & 7 & 1 & 7 & 1 & 7 & 3 & 5 \\
\hline Female & 3 & 9 & 3 & 9 & 4 & 8 & 4 & 8 \\
\hline Total & 4 & 16 & 4 & 16 & 5 & 15 & 7 & 13 \\
\hline
\end{tabular}


Kate Butler recently finished her $\mathrm{PhD}$ at the University of Victoria in the Department of Sociology. Her research examines the experiences of marginalized populations, including children and youth-in-care. She is interested in understanding the ways that citizenship is practiced by individuals on the margins, and the meaning that citizenship has for these groups of people. Her doctoral research was supported by the Social Sciences and Humanities Research Council.

Email: kbutler@uvic.ca

Cecilia Benoit, $\mathrm{PhD}$, is a Professor in the Department of Sociology and Scientist at the Centre for Addictions Research of BC. Apart from research focused on the occupation of midwifery and the organization of maternity care in Canada and internationally, she is involved in a variety of projects that employ mixed methodologies to investigate the health of different vulnerable groups, including street-involved youth in transition to adulthood.

Email: cbenoit@uvic.ca 
50 C Canadian Journal of Sociology/Cahiers canadiens de sociologie 40(1) 2015 